\title{
PENGARUH ASI EKSKLUSIF DAN SUSU FORMULA TERHADAP BERAT BADAN BAYI
}

\author{
Husnul Muthoharoh ${ }^{\bowtie}$ \\ Program Studi Diploma III Kebidanan Sekolah Vokasi Universitas Islam Lamongan
}

\section{ARTICLE INFO \\ Article history \\ Submitted : 2020-12-31 \\ Revised : 2021-10-27 \\ Accepted : 2021-11-24

Keywords:
Infant weight gain
Exclusive breastfeeding
Formula milk

Kata Kunci:

Berat badan bayi

ASI eksklusif

Susu formula

\begin{abstract}
The first and main nutrient intake of breastfed infants is urgently needed for the process of growth and development. The purpose of this is to find out the influence of exclusive breast milk and formula on the baby's weight in Posyandu Jatipayak Village ModoLamongan. This study uses an observational design of case-control analy tic approach that aims to distinguish weight infants at age 1-6 months of exclusive breastfeeding and infant formula. The research instrument was used in the form of interviews and observations with a population of all infants aged $1-6$ months who qualify for inclusion criteria who were 30 toddlers and using a simple random sampling technique. Results of research that babies who are breastfed exclusively have the majority of normal weight increase of $60 \%$, whereas infants who received formula milk most have an abnormal weight gain of $86.67 \%$. Based on the results of Chi-Square $X^{2}=5.167>$ 3.841. This study rejects the Ho that proves that there are differences in body weight in infants aged 1-6 months of exclusive breastfeeding and infant formula. The result of this research is expected mothers to provide breast milk as the best food for babies up to age 6 months.

Asupan nutrisi pertama dan utama bayi yaitu ASI yang sangat dibutuhkan untuk proses tumbuh dan berkembang. Tujuan dari penelitian ini adalah untuk mengetahui pengaruh ASI eksklusif dan susu formula terhadap berat badan bayi di Posyandu Desa Jatipayak Kecamatan Modo-Lamongan. Penelitian ini menggunakan desain observasional analitik dengan pendekatan case control. Instrumen penelitian yang digunakan berupa wawancara dan observasi dengan populasi semua bayi usia $1-6$ bulan yang memenuhi persyaratan kriteria inklusi yang berjumlah 30 balita dan menggunakan teknik simpel random sampling. Hasil penelitian yang dilakukan menunjukkan bahwa bayi yang mendapat ASI eksklusif sebagian besar memiliki kenaikan berat badan normal sebesar $60 \%$, sedangkan bayi yang mendapat susu formula sebagian besar memiliki kenaikan berat badan tidak normal sebesar $86,67 \%$. Berdasarkan hasil uji statistik Chi-Square didapatkan $\mathrm{X}^{2}$ hitung $=5,167>3,841$. Dengan demikian penelitian ini menolak $\mathrm{H}_{\mathrm{o}} \mathrm{y}$ ang membuktikan bahwa terdapat pengaruh ASI eksklusif dan susu formula terhadap berat badan bayi. Sehingga dari hasil penelitian ini diharapkan setiap ibu dapat memberikan ASI eksklusif kepada bayiny a hingga berusia 6 bulan.
\end{abstract}

$\triangle$ Corresponding Author:

Husnul Muthoharoh

Program Studi Diploma III Kebidanan Sekolah Vokasi Universitas Islam Lamongan

Telp. 085749271441

Email: ques.muth@gmail.com

\section{PENDAHULUAN}

Menurut WHO, semua bayi harus diberikan ASI eksklusif selama 6 bulan pertama kehidupan dan melanjutkan pemberian ASI selama 2 tahun atau lebih yang dikombinasikan dengan makanan pendamping ASI (Kajale et al., 2016; Muthoharoh, 2020; Woldeamanuel, 2020). Menyusui memiliki banyak manfaat untuk bayi, diantaranya yakni manfaat dari segi kesehatan, imunologis, psikologis, dan tumbuh kembang. Selama tahun pertama kehidupan, bayi yang diberikan ASI menunjukkan pola pertumbuhan yang berbeda dibandingkan bayi yang diberikan susu formula (Carling et al., 2015; Kajale et al., 2016; Van Dellen et al., 2019; Pangemanan, Prabantoro Ruddy and Susan, 2020). Secara nasional, cakupan bayi yang mendapatkan ASI Eksklusif tahun 2020 yakni sebanyak $66,06 \%$. Jumlah tersebut sudah melewati target Renstra tahun 2020 yakni sebanyak $40 \%$. Persentase tertinggi cakupan pemberian ASI eksklusif terdapat di Provinsi NTB (Nusa Tenggara Barat) yakni sebanyak $87,33 \%$. Sedangkan persentase terendah 
terdapat di Provinsi Papua Barat yakni sebesar $33,96 \%$. Terdapat dua provinsi yang belum mencapai target renstra tahun 2020, yakni Provinsi Maluku dan Papua Barat. Di Jawa Timur pencapaian target ASI Eksklusif masih mencapai $66 \%$ dari $80 \%$ target yang ditetapkan sedangkan di kabupaten Lamongan sebesar $85,6 \%$ (Kemenkes RI, 2021).

Masih rendahnya cakupan ASI eksklusif disebabkan karena beberapa faktor, yakni persediaan pangan di tingkat rumah tangga yang masih terbatas, terbatasnya akses balita sakit terhadap pelayanan kesehatan yang berkualitas yang menyebabkan lima juta bayi menderita gizi kurang. Padahal kekurangan gizi yang terjadi pada bayi akan berdampak pada gangguan psikomotor, kognitif dan sosial serta secara klinis terjadi gangguan pertumbuhan bahkan kematian. Menurut World Health Organization (WHO), sekitar 132 bayi meninggal setiap tahunnya sebelum usia satu tahun, dimana lebih dari setengahnya terkait dengan gizi kurang dan gizi buruk serta penyakit infeksi (Elsira, 2019).

Istilah 1000 hari pertama kehidupan digunakan untuk mendefinisikan suatu periode waktu mulai dari dalam rahim sampai usia 2 tahun. Selama periode ini, bayi mengalami pertumbuhan dan perkembangan yang sangat pesat dan proses ini tidak terjadi pada kelompok umur lain, sehingga disebut juga Golden Age Periode. Oleh karena itu, kecukupan gizi pada masa ini sangat menentukan tumbuh kembang anak di masa depan. Upaya pemenuhan gizi telah dirintis oleh WHO dan UNICEF sejak tahun 2009 dengan mengeluarkan rekomendasi yang diadaptasi dari Global Strategy for Infant and Young Child Feeding yang terdiri dari dua poin utama yakni pemberian ASI eksklusif hingga usia 6 bulan dan pemberian MP-ASI yang aman dan bergizi mulai usia 6 bulan sambil tetap menyusui sampai usia dua tahun atau lebih. Pemberian ASI dan MP-ASI sendiri masih belum sesuai dengan rekomendasi WHO yang diperkirakan hanya $34,8 \%$ bayi di dunia yang mendapatkan ASI eksklusif sedangkan sisanya mendapatkan makanan dan cairan lain sejak usia kurang dari 6 bulan (Rusmil et al., 2019; Van Dellen et al., 2019).

Masih banyak Ibu yang produksi ASI nya tidak bisa mencukupi kebutuhan bayi sehingga hal ini menjadi alasan Ibu mengombinasikan pemberian ASI dengan susu formula pada bayinya. Hal ini disebabkan karena kurangnya kemampuan dalam manajemen laktasi dan kurangnya dukungan sosial yang diberikan kepada Ibu (PérezEscamilla et al., 2019).Sangat sedikit yang mengetahui tentang penggunaan susu formula berdasarkan jenis, jumlah, cara pemberian, dan pertambahan berat badan di awal kehidupan. Susu formula yang terhidrolisis tampaknya lebih mudah diserap, dapat memberikan respon rasa kenyang yang berbeda, dan dapat mempengaruhi berat badan secara berbeda dibandingkan dengan susu formula biasa. Selain itu, konsumsi susu formula di atas pedoman yang direkomendasikan dan kesalahan dalam memberikan takaran susu formula bubuk juga dapat menyebabkan pertambahan berat badan dengan cepat (Graulau et al., 2019).

Bayi usia 6 bulan mengalami pertambahan berat badan sebesar 150-210 gram/minggu dan panjang badan lahir normal adalah $45-50 \mathrm{~cm}$, berdasarkan kurva pertambahan berat badan yang diterbitkan oleh National Center for Health Statistics (NCHS). Berat badan bayi normal yakni 2500 gram, apabila kurang dari 2.500 gram dikatakan bayi memiliki berat badan lahir rendah (BBLR), sedangkan bila lebih dari 3.500 gram dikatakan makrosomia. Setiap bulan bayi akan mengalami penambahan panjang badan sekitar $2,5 \mathrm{~cm}$. Pada masa bayi-balita, berat badan dan panjang badan digunakan sebagai patokan untuk mengetahui pertumbuhan fisik dan status gizi yang erat kaitannya dengan pertumbuhan bayi (Elsira, 2019; Vargas-Terrones, Nagpal and Barakat, 2019).

Penelitian sebelumnya yang dilakukan oleh (Yustianingrum and Adriani, 2017) didapatkan hasil yakni status gizi baik anak baduta ASI eksklusif yaitu 95,5\% dan non ASI eksklusif yaitu $59,1 \%$. Kejadian penyakit infeksi pada anak baduta ASI eksklusif yaitu $27,3 \%$ dan non ASI eksklusif yaitu $81,8 \%$. Hasil dari penelitian pada kedua kelompok menunjukkan ada perbedaan signifikan $(p<0,05)$ pada status gizi dan kejadian penyakit infeksi.

\section{METODE PENELITIAN}

\section{Jenis Penelitian}

Metode penelitian bersifat kuantitatif dengan desain observasional analitik dengan rancangan penelitian berupa Case Control. Pada penelitian ini subjek yang digunakan adalah 
manusia. Peneliti sudah mendapat ijin dari komite etik penelitian Fakultas kesehatan Universitas Islam Lamongan.

\section{Lokasi dan Waktu Penelitian}

Penelitian dilakukan di Posyandu Desa Jatipayak, Kecamatan Modo, Kabupaten Lamongan pada bulan Juni - Agustus 2020.

\section{Populasi dan Sampel}

Populasi dalam penelitian ini adalah semua bayi usia $1-6$ bulan yang rutin datang dan terdaftar di posyandu Jatipayak. Teknik pengambilan sampel menggunakan teknik simple random sampling dengan jumlah sampel sebanyak 30 bayi.

\section{Pengumpulan Data}

Alat ukur yang digunakan untuk pengumpulan data dalam penelitian ini berbentuk observasi melalui KMS pertumbuhan balita untuk mengetahui kenaikan berat badan bayi usia 1 6 bulan yang ditimbang secara rutin di posyandu dan melakukan kegiatan wawancara dengan kuesioner kepada ibu untuk mengetahui bayi yang mendapat ASI eksklusif atau bayi yang mendapat susu formula selama 6 bulan.

\section{Pengolahan dan Analisis Data}

Data yang diperoleh kemudian diolah dan dianalisis secara analitik untuk mengetahui tentang perbedaan berat badan bayi usia $1-6$ bulan antara yang mendapat ASI eksklusif dengan yang mendapat susu formula. Analisis data yang digunakan adalah untuk mengetahui hubungan dua variabel yaitu variabel independen dan variabel dependen, maka digunakan uji chi square $\left(\mathrm{X}^{2}\right)$, tingkat kemaknaan dalam penelitian ini adalah $\alpha \leq 0,05$ artinya bila nilai $\alpha \leq 0,05$ maka Ho ditolak berarti ada signifikan atau pengaruh yang bermakna antara variabel yang diukur bila nilai $\alpha \geq 0,05$ maka $\mathrm{H}_{1}$ diterima artinya ada pengaruh yang bermakna antara variabel yang diukur.

\section{HASIL PENELITIAN}

Penelitian ini dilakukan pada 30 responden. Hasil penelitian pada tabel 1 tentang distribusi frekuensi karakteristik subyek penelitian berdasarkan karakteristik Ibu, didapatkan hasil bahwa sebagian besar responden berumur $20-30$ tahun, sebagian besar responden berpendidikan SMA, dan tidak bekerja. Hasil penelitian berdasarkan tabel 2 menunjukkan bahwa mayoritas anak berusia 0 2 bulan dan mayoritas berjenis kelamin perempuan.

Tabel 1. Karakte ristik Ibu

\begin{tabular}{lcc}
\hline \multirow{2}{*}{ Indikator } & \multicolumn{2}{c}{ Jumlah } \\
\cline { 2 - 3 } & Frekuensi (n) & Persentase (\%) \\
\hline Usia (Tahun) & 2 & 6,66 \\
$<20$ & 17 & 56,67 \\
$20-30$ & 11 & 36,67 \\
$>30$ & & \\
Pendidikan & 6 & 20 \\
SLTP & 21 & 70 \\
SLTA & 3 & 10 \\
PT & & \\
Pekerjaan & 13 & 43,33 \\
Bekerja & 17 & 56,67 \\
Tidak bekerja &
\end{tabular}

Hasil analisa bivariat berdasarkan tabel 3 menunjukkan bahwa dari 30 responden bayi, yang mendapat susu formula sebagian besar mengalami kenaikan berat badan tidak normal yaitu 68,42 \% dan yang mendapat ASI eksklusif mayoritas mengalami kenaikan berat badan normal $81,82 \%$. Dari perhitungan uji $c h i$ - square didapatkan nilai $\mathrm{x}^{2}$ hitung $=5,167$ $>3,841$, sehingga $\mathrm{H}_{0}$ ditolak. Dengan demikian dapat disimpulkan bahwa ada perbedaan berat badan pada bayi usia $1-6$ bulan terhadap pemberian ASI eksklusif dan susu formula. 
Tabel 2. Karakteristik Anak

\begin{tabular}{ccc}
\hline \multirow{2}{*}{ Indikator } & \multicolumn{2}{c}{ Jumlah } \\
\cline { 2 - 3 } & Frekuensi (n) & Persentase (\%) \\
\hline Umur & 14 & 46,67 \\
$0-2$ bulan & 10 & 33,33 \\
$3-4$ bulan & 6 & 20 \\
$5-6$ bulan & & \\
Jenis Kelamin & 13 & 43,33 \\
Laki-laki & 17 & 56,67 \\
Perempuan & & \\
\hline
\end{tabular}

\section{PEMBAHASAN}

Hasil penelitian menunjukkan bahwa terdapat pengaruh ASI eksklusif dan susu formula terhadap berat badan bayi, karena pemberian ASI eksklusif hingga umur 6 bulan akan menjamin tercapainya pertumbuhan anak secara optimal. Hal ini sejalan dengan penelitian (Saswita and Dian, 2019) di mana ada perbedaan yang signifikan antara berat badan bayi yang diberi ASI eksklusif dan bayi yang tidak diberi ASI eksklusif, bayi yang diberi ASI eksklusif cenderung mempunyai berat badan normal dan bayi yang tidak diberi ASI eksklusif cenderung mengalami kegemukan. Hal ini karena selain sebagai nutrien yang tepat, serta disesuaikan dengan kebutuhan bayi, ASI juga mengandung makro dan mikro nutrien, komponen kekebalan, dan termasuk di dalamnya terdapat asam amino bebas (Free Amino Acids) yang diperlukan dalam mendukung pertumbuhan dan perkembangan bayi (Baldeón et al., 2019).

Beberapa zat gizi khusus yang terkandung di dalam ASI tersebut, tidak terdapat dalam susu formula. Sehingga semua zat gizi yang dibutuhkan bayi untuk pertumbuhan pada bulan pertama kehidupannya dapat dipenuhi dari ASI. Pertumbuhan antara berat badan dan tinggi badan ada hubungan yang linear jika pertumbuhan anak normal. Pemberian ASI saja juga dapat mempengaruhi peningkatan berat badan dan tinggi badan agar pertumbuhan seimbang (Zaenab, Alasiry and Idris, 2016). Bayi yang mendapatkan ASI eksklusif berat badannya bertambah 500-700 gram lebih sedikit di tahun pertama usia mereka dibandingkan dengan bayi yang mendapatkan susu formula. Hal ini tampaknya secara kausal berkaitan dengan rendahnya risiko obesitas di kemudian hari (Prell and Koletzko, 2016; Lemaire, Le Huerou-Luron and Blat, 2018).

Tabel 3. Perbedaan Kenaikan BB Bayi Usia 1 - 6 Bulan antara yang Mendapat ASI Eksklusif dan Susu Formula di Posyandu Desa Jatipayak Kecamatan Modo Kabupaten Lamongan

\begin{tabular}{ccccccc}
\hline \multirow{2}{*}{ Pola Pemberian } & \multicolumn{4}{c}{ Kenaikan B B } & \multicolumn{2}{c}{ Total } \\
\cline { 2 - 6 } ASI & \multicolumn{2}{c}{ Tidak Normal } & \multicolumn{2}{c}{ Normal } & \multicolumn{2}{c}{} \\
\cline { 2 - 6 } & $\mathbf{n}$ & $\mathbf{\%}$ & $\mathbf{n}$ & $\mathbf{\%}$ & $\mathbf{n}$ & $\mathbf{\%}$ \\
\hline Susu Formula & 13 & 68,42 & 6 & 31,58 & 19 & 100 \\
ASI Eksklusif & 2 & 18,18 & 9 & 81,82 & 11 & 100 \\
Total & 15 & 50 & 15 & 50 & 30 & 100 \\
\hline & \multicolumn{1}{l}{$\mathrm{X}^{2}$ hitung $=5,167$} & & & \multicolumn{2}{c}{$\mathrm{p}<0,05$} \\
\hline
\end{tabular}

Nutrisi di awal kehidupan bayi diketahui memainkan peran mendasar dalam mengatur perkembangan dan pematangan fungsi jaringan dan organ spesifik jangka pendek dan panjang. Sehingga bulan pertama kehidupan bayi merupakan waktu yang kritis untuk mencegah gangguan metabolisme, kardiovaskuler, dan obesitas di kemudian hari. Lintasan pertumbuhan bayi dan kenaikan berat badan selama tahun pertama kehidupan merupakan salah satu prediktor terbaik dari obesitas di kemudian hari, dengan peningkatan 
1 SD dalam skor-z berat badan dikaitkan dengan risiko obesitas 2 kali lipat lebih tinggi di masa kanak-kanak dan $23 \%$ risiko obesitas lebih tinggi di masa dewasa (Lemaire, Le Huërou-Luron and Blat, 2018). Bayi berusia 06 bulan yang mendapatkan ASI eksklusif memiliki pola penambahan berat badan yang normal dikarenakan ASI merupakan satusatunya makanan utama dan terbaik bagi bayi hingga usia 6 bulan. ASI mengandung sumber gizi yang sangat penting dan sesuai dengan kebutuhan bayi dan juga memiliki komposisi yang seimbang dan sempurna bagi pertumbuhan bayi sampai usia 6 bulan. Di samping itu, ASI juga mengandung 7 hormon dan 13 faktor pertumbuhan (growth factors) yang penting bagi pertumbuhan bayi. Bayi yang diberikan ASI eksklusif, kebutuhan gizinya akan tercukupi sehingga daya tahan tubuh bayi akan meningkat dan akan berpengaruh terhadap pertumbuhannya, sedangkan pertumbuhan berat badan bayi yang tidak normal pada bayi yang mendapat susu formula. Kebiasaan pemberian makanan tambahan yang terlalu dini pada bayi usia kurang dari 6 bulan akan menyebabkan bayi menyusu lebih sedikit, hal ini disebabkan ukuran perut bayi masih kecil sehingga mudah penuh, sedangkan kebutuhan gizi belum terpenuhi akibatnya proses pertumbuhan akan terganggu. Selain itu, penggunaan susu formula yang terlalu encer juga dapat mengakibatkan kurangnya asupan nutrisi yang dibutuhkan sehingga bayi akan terjatuh dalam kondisi status gizi kurang yang akan mempengaruhi pertumbuhannya (Muthoharoh, 2020).

Hasil penelitian ini juga sejalan dengan penelitian (Elsira, 2019) di mana terdapat perbedaan kenaikan berat badan pada bayi dengan pemberian ASI eksklusif dan ASI parsial di Puskesmas Kalidoni Palembang tahun 2018. Rata-rata pertambahan berat badan bayi yang diberi ASI eksklusif adalah 4260 gram dengan standar deviasi 140,408 gram, sedangkan untuk bayi yang diberi ASI parsial rata-rata pertambahan berat badan bayi adalah 4580 gram dengan standar deviasi adalah 214,476 gram. Perbedaan nilai rata-rata pertambahan berat badan antara bayi yang diberi ASI eksklusif dan bayi yang di beri ASI parsial adalah 320 . Hasil uji statistik didapatkan nilai $\mathrm{p}$ value $=0,000<\alpha(0,05)$ berarti $\mathrm{H} 0$ ditolak. Terlihat bahwa ada perbedaan yang signifikan pertambahan berat badan antara bayi yang diberi ASI eksklusif dibandingkan dengan bayi yang diberi ASI parsial dilihat dari nilai $\mathrm{p}$ value $=0,000<\alpha(0,05)$. ASI memiliki kandungan yang kompleks dengan komposisi umum $87 \%$ air, $3.8 \%$ lemak, $1.0 \%$ protein, dan $7 \%$ laktosa. Lemak dan laktosa masing-masing menyediakan sebanyak 50\% dan $40 \%$ dari total energi susu. Komposisi ASI bersifat dinamis dan berubah dari waktu ke waktu menyesuaikan dengan perubahan kebutuhan bayi yang sedang tumbuh. ASI yang keluar di awal waktu menyusui (foremilk) lebih encer dengan kandungan laktosa lebih tinggi sehingga bisa menghilangkan dahaga bayi. ASI yang dikeluarkan di akhir waktu menyusui (hindmilk) lebih kental dan pekat dengan kandungan lemak yang jauh lebih tinggi (Martin, Ling and Blackburn, 2016).

\section{KESIMPULAN DAN SARAN}

Sebagian besar bayi yang mendapatkan ASI eksklusif memiliki kenaikan berat badan yang normal, dan sebaliknya sebagian besar bayi yang mendapatkan susu formula memiliki kenaikan berat badan yang tidak normal. Ada perbedaan berat badan pada bayi usia $1-6$ bulan terhadap pemberian ASI eksklusif dan susu formula di Posyandu Desa Jatipayak Kecamatan Modo Lamongan dengan $\mathrm{p}<0,05$. Dari hasil penelitian ini diharapkan ibu-ibu dapat memberikan ASI sebagai makanan terbaik bagi bayinya hingga mencapai usia 6 bulan.

\section{DAFTAR PUSTAKA}

Baldeón, M. E. et al. (2019) 'Free amino acid content in human milk is associated with infant gender and weight gain during the first four months of lactation', Nutrients, 11(9). doi: 10.3390/nu11092239.

Carling, S. J. et al. (2015) 'Breastfeeding duration and weight gain trajectory in infancy', Pediatrics, 135(1), pp. 111-119. doi: 10.1542/peds.2014-1392.

Van Dellen, S. A. et al. (2019) 'The effect of a breastfeeding support programme on breastfeeding duration and exclusivity: a quasi-experiment', BMC public health. BMC Public Health, 19(1), p. 993. doi: 10.1186/s12889-019-7331-y.

Elsira, N. (2019) 'Perbedaan Kenaikan Berat Badan Pada Bayi Dengan Pemberian Asi Eksklusif Dan Asi Parsial Di Puskesmas Kalidoni Palembang', Jurnal Kesehatan dan Pembangunan, 9(18), pp. 60-68. 
Available at: http://ejurnal.stikesmitraadiguna.ac.id/index.php /jkp/article/view/44.

Graulau, R. E. et al. (2019) 'Amount, preparation and type of formula consumed and its association withweight gain in infants participating in the wic program in hawaii and puerto rico', Nutrients, 11(3). doi: 10.3390/nu11030695.

Kajale, N. A. et al. (2016) 'Effect of Breastfeeding Practices and Maternal Nutrition on Baby's Weight Gain During First 6 Months', Journal of Obstetrics and Gynecology of India. Springer India, 66(1), pp. 335-339. doi: 10.1007/s13224016-0918-7.

Kemenkes RI (2021) Profil Kesehatan Indonesia 2020, Kementrian Kesehatan Republik Indonesia. Available at: https://pusdatin.kemkes.go.id/resources/d ownload/pusdatin/profil-kesehatanindonesia/Profil-Kesehatan-IndonesiaTahun-2020.pdf.

Lemaire, M., Le Huërou-Luron, I. and Blat, S. (2018) 'Effects of infant formula composition on long-term metabolic health', Journal of Developmental Origins of Health and Disease, 9(6), pp. 573-589. doi: 10.1017/S2040174417000964.

Martin, C. R., Ling, P. R. and Blackburn, G. L. (2016) 'Review of infant feeding: Key features of breast milk and infant formula', Nutrients, 8(5), pp. 1-11. doi: 10.3390/nu8050279.

Muthoharoh, H. (2020) 'Pemberian Makanan Pendamping Air Susu Ibu Secara Dini Pada Bayi Usia 0-6 Bulan Berdasarkan Pengetahuan Keluarga', Window of Health: Jurnal Kesehatan, 3(3), pp. 259266.

Pangemanan, L., Prabantoro Ruddy, B. . and Susan, S. (2020) 'Dampak Pemberian Inisiasi Menyusu Dini dan Air Susu Ibu Eksklusif pada Pertumbuhan Bayi Usia Satu sampai Enam Bulan', Widya Medika, 6(2), pp. 111-120.

Pérez-Escamilla, R. et al. (2019) 'Perspective: Should Exclusive Breastfeeding Still Be Recommended for 6 Months?', Advances in Nutrition. Oxford University Press, 10(6), pp. 931-943. doi: 10.1093/advances/nmz039.

Prell, C. and Koletzko, B. (2016) 'Breastfeeding and Complementary Feeding', Deutsches Arzteblatt International, 113(25), pp. 435-444. doi: 10.3238/arztebl.2016.0435.

Rusmil, V. K. et al. (2019) 'Exclusive and NonExclusive Breastfeeding among Stunted and Normal 6-9 Month-Old-Children in Jatinangor Subdistrict, Indonesia', Althea Medical Journal, 6(1), pp. 35-41. doi: 10.15850/amj.v6n1.1598.

Saswita, R. and Dian, P. W. (2019) 'Perbedaan Peningkatan Berat Badan Pada Bayi Usia 6-12 Bulan Yang Diberi Asi Eksklusif Dan Non Asi Eksklusif Di Bpm Ch Mala Husin ...', Masker Medika, 7(1), pp. 1118. Available at: http//ejournal. stikesmp.ac.id/index.php/maskermedika/ article/view/297.

Vargas-Terrones, M., Nagpal, T. S. and Barakat, R. (2019) 'Impact of exercise during pregnancy on gestational weight gain and birth weight: an overview', Brazilian Journal of Physical Therapy, 23(2), pp. 164-169. doi: 10.1016/j.bjpt.2018.11.012.

Woldeamanuel, B. T. (2020) 'Trends and factors associated to early initiation of breastfeeding, exclusive breastfeeding and duration of breastfeeding in Ethiopia: Evidence from the Ethiopia Demographic and Health Survey 2016', International Breastfeeding Journal. International Breastfeeding Journal, 15(1), pp. 1-13. doi: 10.1186/s13006-019-0248-3.

Yustianingrum, L. N. and Adriani, M. (2017) 'Perbedaan Status Gizi dan Penyakit Infeksi pada Anak Baduta yang Diberi ASI Eksklusif dan Non ASI Eksklusif', Amerta Nutrition, 1(4), p. 415. doi: 10.20473/amnt.v1i4.7128.

Zaenab, S., Alasiry, E. and Idris, I. (2016) 'Pengaruh Pemberian ASI Eksklusif Terhadap Pertumbuhan Bayi di Wilayah Kerja Puskesmas Poasia Kota Kendari', Jurnal Ilmu Kesehatan, 6(1), pp. 97-102. 